\section{Mechanical String Thinner Reduces Crop Load at Variable Stages of Bloom Development of Peach and Nectarine Trees}

\author{
T. Auxt Baugher ${ }^{1}$, K. Ellis, J. Remcheck, and K. Lesser \\ The Pennsylvania State University, Penn State Cooperative Extension in \\ Adams County, 670 Old Harrisburg Road, Gettysburg, PA 17325
}

\section{J. Schupp, E. Winzeler, and K. Reichard \\ The Pennsylvania State University Fruit Research and Extension Center, 290 University Drive, Biglerville, PA 17307}

Additional index words. Prunus persica, mechanical bloom thinning, thinning, quality, set, labor efficiency, stone fruit

\begin{abstract}
Thinning of blossoms or fruitlets is a labor-intensive requirement in the production of peach and nectarine (Prunus persica) fruit of optimum size and quality. Prior research conducted by the authors on string blossom thinners for managing peach tree crop load demonstrated that this new technology reduces labor requirement and improves fruit size. The research reported in the current article was conducted over 2 years on 'Sugar Giant' peach and 'Arctic Sweet' nectarine to evaluate string blossom thinner efficacy at variable stages of bloom development ranging from pink to petal fall. Blossom removal at the pink stage of bloom development was lower than at other stages in 2008; however, a 150-rpm versus 120-rpm spindle rotation speed resulted in blossom removal similar to the $80 \%$ full bloom (FB) treatment in 2009 . Blossom removal at the petal fall stage was similar to the open bloom stage with the exception of the 2009 'Sugar Giant' trial, in which blossom removal was higher at $80 \%$ FB. Flower density and fruit set of the bloom stage compared with hand-thinned control treatments followed a similar trend with the exception that there were fewer differences in 2009 and in lower canopy regions. Follow-up hand thinning time was reduced by all string thinning/year combinations except 'Arctic Sweet' at pink in 2008 and 2009 and at petal fall in 2009. The best treatments reduced follow-up hand thinning time compared with green fruit hand thinning alone by $51 \%$ and $41 \%$ for 'Sugar Giant' and by $42 \%$ and $22 \%$ for 'Arctic Sweet' in Years 1 and 2, respectively. In 2008, the percentage of fruit in the $" 7.0 \mathrm{~cm}$ or greater" size category was increased by all bloom stage treatments in both cultivars. The 2009 size distribution of 'Arctic Sweet' fruit was unaffected, but the percentage of 'Sugar Giant' fruit in higher market value size categories was increased by the $80 \% \mathrm{FB}$ and higher rpm pink treatments. Savings in hand thinning time and/or increases in fruit size in both years associated with the bloom stage treatments resulted in a net positive impact of $\$ 123 /$ ha to $1368 /$ ha compared with hand thinning alone.
\end{abstract}

Tree fruit typically set an excessive number of fruit, and blossom or fruit thinning is required to ensure that the remaining fruit attain marketable size. The conventional method for adjusting crop load in peach and nectarine orchards is to remove excess fruit by hand at 35 to $40 \mathrm{~d}$ after full bloom (DAFB). This is one of the more labor-intensive practices in stone fruit production with the time for hand thinning ranging from $62 \mathrm{~h} \cdot \mathrm{ha}^{-1}$ to over $247 \mathrm{~h} \cdot \mathrm{ha}^{-1}$ (Glozer and Hasey, 2006; Krawczyk, 2010). Plant growth regulators are available for thinning pome fruit; however, chemical thinning options for stone fruit are limited and unpredictable (Stover and Greene, 2005). Three years of research on chemical blossom thinners (Baugher et al., 2008) demonstrated that although the treatments often increased peach fruit size, they were inconsistent in reducing follow-up hand thinning requirement. These results are similar to reports ever, several trials included string thinning treatments at pink or $20 \%$ full bloom (FB), and fruit size was improved compared with treatments applied at later bloom stages (Baugher et al., 2009; Schupp et al., 2008).

A 2-year study was initiated in 2008 to evaluate string blossom thinning at variable stages of bloom development ranging from pink to petal fall. The objectives were to assess the effects of mechanical thinning at various bloom stages compared with conventional green fruit hand thinning: 1) on blossom removal and follow-up hand thinning requirement; and 2) on crop load, fruit size, and net economic impact.

\section{Materials and Methods}

Mechanical string thinner description. The string thinner was originally designed to remove apple blossoms in organic orchards trained to narrow conical systems (Bertschinger et al., 1998). The thinner (Darwin 300; FruitTec, Deggenhausertal, Germany) has a 3.0$\mathrm{m}$-long spindle that is oriented in a vertical position and tilts $30^{\circ}$ in either direction from center (Fig. 1). The spindle is turned by a hydraulic motor and speed is adjusted by a proportional flow control valve. The height and angle of the frame supporting the spindle are adjustable to conform to the height and inclination of the tree canopy, and the intensity of thinning is adjustable by changing the spindle rotation speed, the tractor speed, and the string arrangement. String length was 50 $\mathrm{cm}$. Two columns of cords were used, arranged with alternating gaps (Fig. 2). The string thinner was fitted with plastic cords and operated at $180 \mathrm{rpm}$ and $4.0 \mathrm{~km} \cdot \mathrm{h}^{-1}$ in 2008 and fitted with molded cords and operated at $150 \mathrm{rpm}$ and $4.0 \mathrm{~km} \cdot \mathrm{h}^{-1}$ in 2009 (with the exception of a second pink treatment conducted at $120 \mathrm{rpm}$ ). The string thinner manufacturer changed the string technology in 2009, and it was important to test the strings that commercial growers would be using as they adopted the non-selective thinning strategy. Extensive pre-tests were conducted in 2009 to ensure that the string arrangement, $\mathrm{rpm}$, and tractor speed used with both string types produced similar levels of thinning.

Commercial orchard trials conducted over two seasons. Mechanical thinning trials were conducted over two seasons in commercial plantings of mature 'Sugar Giant' peach trees and 'Arctic Sweet' nectarine trees on Arendtsville gravelly loam soil. The orchards were located in Biglerville, PA, and were trained to narrow canopy (60 to $75 \mathrm{~cm})$, perpendicular V systems. Bloom stage treatments included pink, 20\% FB, $80 \% \mathrm{FB}$, and petal fall in 2008 and pink at $150 \mathrm{rpm}$, pink at $120 \mathrm{rpm}, 80 \% \mathrm{FB}$, and petal fall in 2009 .

The experimental design in each trial was a randomized complete block with six blocks and six-tree plots. Data were collected from two center trees in each plot. The mechanical treatments in all trials were compared with hand thinning at 35 to 40 DAFB. Flower density and crop load were determined on two pre-tagged scaffolds on each of the test 
trees. Initial blossom density ranged from six to nine flowers $/ \mathrm{cm}^{2} \mathrm{limb}$ cross-sectional area in 2008 and from three to nine flowers $/ \mathrm{cm}^{2}$ limb cross-sectional area in 2009. Blossom removal with mechanical thinners was evaluated by counting all blossoms in the upper (1.5- to 3.0-m height) and lower (0.5- to 1.5$\mathrm{m}$ height) canopy regions of the tagged scaffolds immediately before and after thinning. The total number of blossoms per scaffold also was compared. Reduction in flower/fruit density was evaluated the day of thinning and again after physiological drop (35 to 40 DAFB) by calculating number of blossoms or fruit per limb cross-sectional area in the upper and lower canopy. All trees were uniformly hand thinned by growers to commercial levels, during which follow-up hand thinning time was recorded. At harvest, a sample of 40 to 50 firm-ripe fruit collected from the two center trees in each plot was evaluated for mean fruit diameter, fruit size distribution, and possible defects from mechanical thinning. Yields were calculated from fruit per scaffold counts and percent size distribution. All data were subjected to an analysis of variance and treatments were separated using Fisher's protected least significant difference test.

Economic partial budget analyses (described by Harper et al., 2002) were performed to evaluate the potential impact of each thinning treatment on fruit returns. Mechanical thinning costs were based on a 15-year useful life of equipment (commercially available price of $\$ 13,280$ ) and $8 \%$ interest rate averaged $\$ 37 /$ ha for the string thinner, including tractor cost $(\$ 12.00 / \mathrm{h})$ and labor $(\$ 12.00 / \mathrm{h})$. Realized economic savings were calculated from follow-up hand thinning time, fruit size distribution, and average yield. Follow-up hand thinning costs were

Received for publication 11 May 2010. Accepted for publication 28 June 2010.

This research was supported by the USDA Specialty Crop Research Initiative, by the State Horticultural Association of Pennsylvania Extension Committee, by the Pennsylvania Peach and Nectarine Board, by the Washington Tree Fruit Research Commission, by the Penn State College of Agriculture Seed Grant Program, by the Pennsylvania Department of Community and Economic Development First Industries Program, and by the Adams County Economic Development Corporation.

We acknowledge the valuable contributions of C. Musselman, A. Leslie, J. Koan, R. Rohrbaugh, M. Reid, C. Anders, E. Moore, C. Kuntz, C. Witt, M. Tindall, T. Salada, E. Anderson, F. Showers, C. Sollenberger, M. Price, A. Betz, S. Betz, D. Kilmer, J. Cline, S. Aguilar, J. Lott, D. Kuhn, R. Lamb, S. Kuhn, D. Mickey, J. Mickey, D. Wenk, B. Wenk, J. Wenk, E. Rankin, A. Dias, C. Baugher, D. Lott, C. McCleaf, M. Rice, D. Slaybaugh, and B. Knouse. The mention of a trademark, proprietary product, or vendor does not constitute a guarantee or warranty of the product and does not imply its approval to the exclusion of other products or vendors that also may be suitable.

${ }^{1}$ To whom reprint requests should be addressed; e-mail tab36@psu.edu.

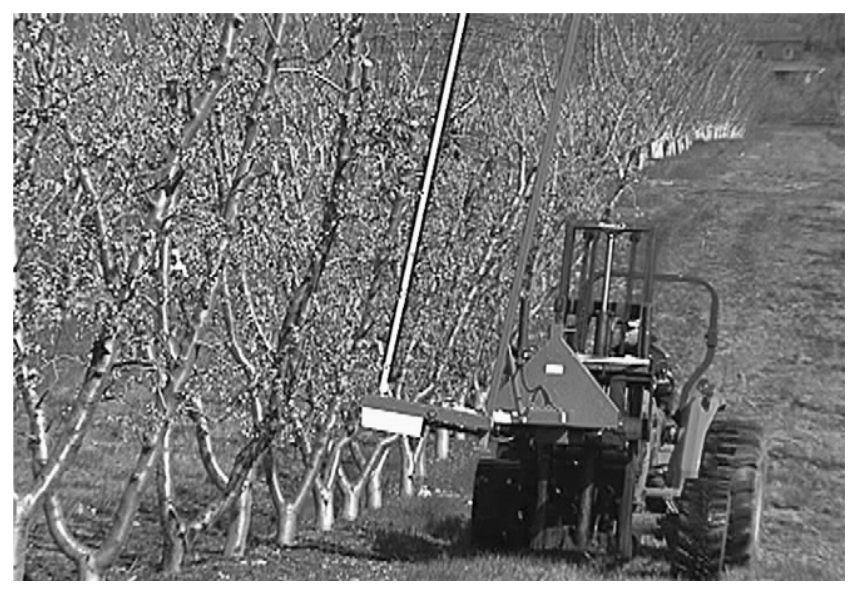

Fig. 1. A rotating string thinner for narrow vertical canopies was used to thin peach and nectarine trees trained to a perpendicular $\mathrm{V}$ system. The spindle is $3.0 \mathrm{~m}$ in length and tilts $30^{\circ}$ either direction from center. Photograph by M. Wherley.
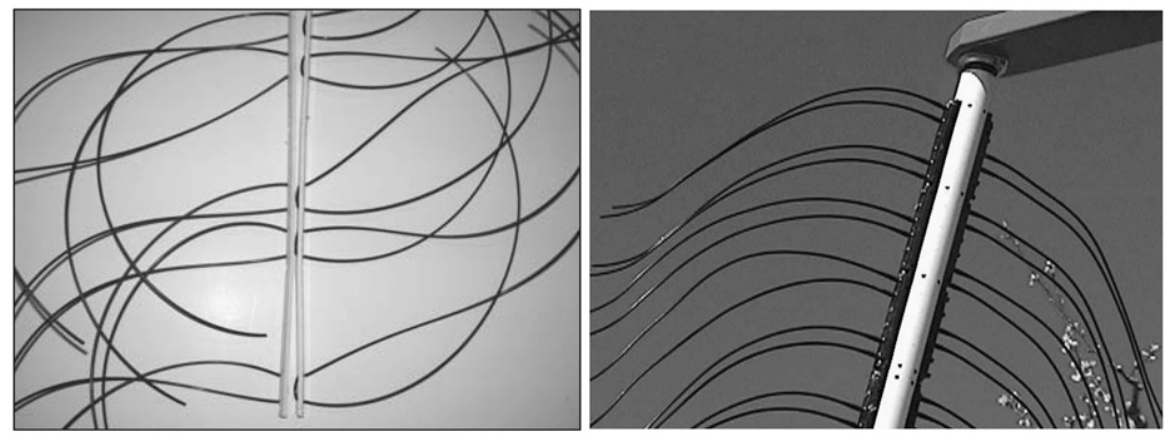

A

B

Fig. 2. The string thinner spindle was fitted with two columns of cords arranged with alternating gaps Plastic cords (A) made for pre-2009 versions of the string thinner were used in 2008 and molded cords (B) developed for 2009 and 2010 string thinner models were used in 2009. Extensive pre-tests were conducted to ensure that the string arrangement, rpm, and tractor speed used with both string types produced similar levels of thinning.

based on a labor rate of $\$ 8.50 / \mathrm{h}$ in 2008 and $\$ 8.75 / \mathrm{h}$ in 2009 . Commercial prices for the various size categories for each cultivar and year were obtained from the USDA Agricultural Marketing Service Report, Appalachian Region (U.S. Department of Agriculture, 2009).

\section{Results and Discussion}

Blossom removal, flower density, fruit set, and follow-up hand thinning comparisons. Blossom removal with the string thinner was significant across years, cultivars, and canopy regions for the various bloom stages in which there were open flowers (Fig. 3). Blossom removal at the pink stage of bloom development was lower than at other stages in 2008; however, a 150 -rpm versus 120 -rpm spindle rotation speed resulted in blossom removal similar to the $80 \%$ FB treatment in 2009 . Blossom removal at the petal fall stage was similar to the open bloom stage with the exception of the 2009 'Sugar Giant' trial, in which blossom removal was higher at petal fall. Percent blossom removal for the most effective treatments ranged from 38 to 60 in 2008 and 30 to 50 in 2009. The increased blossom removal at higher spindle speeds is consistent with results reported in a multistate mechanical thinning project conducted in 2009 (Baugher et al., 2010).

Flower density immediately after thinning and fruit set of the bloom stage compared with hand thinned control treatments followed a similar trend with the exception that there were fewer differences in 2009 and in lower canopy regions (Table 1). The year 2009 was a lighter crop year compared with 2008 with the hand thinned control bloom being only 3.1 flowers $/ \mathrm{cm}^{2}$ limb cross-sectional area in 'Arctic Sweet'. The best treatments reduced flower density in upper canopy regions by $60 \%, 63 \%, 64 \%$, and $27 \%$ for 'Sugar Giant' and 'Arctic Sweet' in Years 1 and 2, respectively. The corresponding decreases in crop density, measured at 35 to 40 DAFB and before follow-up hand thinning, were $50 \%$, $41 \%, 48 \%$, and $25 \%$, respectively.

As a further illustration of the differences in initial crop potential between the 2 years, hand thinning time for the green fruit thinned control treatments averaged $144 \mathrm{~h} \cdot \mathrm{ha}^{-1}$ in 2008 and $34 \mathrm{~h} \cdot \mathrm{ha}^{-1}$ in 2009 (Table 2). Follow-up hand thinning time was reduced by all treatment and year combinations except the 'Arctic Sweet' at pink in 2008 and 2009 and at petal fall in 2009. The best treatments reduced 
Table 1. 'Sugar Giant' peach and 'Arctic Sweet' nectarine flower and fruit density response to string thinner treatments at varying bloom stages compared with hand thinned controls in 2008 and 2009.

\begin{tabular}{|c|c|c|c|c|c|c|}
\hline \multirow[b]{2}{*}{ Thinning treatment ${ }^{z}$} & \multicolumn{3}{|c|}{$\begin{array}{c}\text { Flower density after } \\
\text { thinning (flowers } / \mathrm{cm}^{2} \text { limb-cross-sectional area) }\end{array}$} & \multicolumn{3}{|c|}{$\begin{array}{c}\text { Crop load (density) at } 35 \mathrm{DAFB}^{\mathrm{y}} \\
\text { (fruit } / \mathrm{cm}^{2} \text { limb-cross-sectional area) }\end{array}$} \\
\hline & Upper canopy & Lower canopy & Scaffold & Upper canopy & Lower canopy & $\overline{\text { Scaffold }}$ \\
\hline \multicolumn{7}{|c|}{ 'Sugar Giant' 2008} \\
\hline Pink & $10.4 \mathrm{a}^{\mathrm{w}}$ & $3.9 \mathrm{a}$ & $9.1 \mathrm{a}$ & $4.5 \mathrm{ab}$ & $1.8 \mathrm{a}$ & $4.0 \mathrm{ab}$ \\
\hline $20 \% \mathrm{FB}^{\mathrm{x}}$ & $5.4 \mathrm{~b}$ & $1.7 \mathrm{~b}$ & $4.6 \mathrm{~b}$ & $3.0 \mathrm{bc}$ & $0.7 \mathrm{~b}$ & $2.3 \mathrm{c}$ \\
\hline $80 \%$ FB & $5.4 \mathrm{~b}$ & $2.0 \mathrm{~b}$ & $4.7 \mathrm{~b}$ & $3.0 \mathrm{bc}$ & $1.0 \mathrm{ab}$ & $2.5 \mathrm{ab}$ \\
\hline Petal fall & $4.2 \mathrm{~b}$ & $2.1 \mathrm{~b}$ & $4.4 \mathrm{~b}$ & $2.3 \mathrm{c}$ & $0.9 \mathrm{~b}$ & $2.2 \mathrm{c}$ \\
\hline Hand thinned control, 35 DAFB & $10.5 \mathrm{a}$ & $3.9 \mathrm{a}$ & $9.0 \mathrm{a}$ & $5.3 \mathrm{a}$ & $1.8 \mathrm{a}$ & $4.4 \mathrm{a}$ \\
\hline \multicolumn{7}{|c|}{ 'Sugar Giant' 2009} \\
\hline Pink, $150 \mathrm{rpm}$ & $6.1 \mathrm{~b}$ & $1.8 \mathrm{bc}$ & $6.4 \mathrm{~b}$ & $2.3 \mathrm{~b}$ & $0.7 \mathrm{ab}$ & $2.4 \mathrm{ab}$ \\
\hline Pink, $120 \mathrm{rpm}$ & $5.8 \mathrm{~b}$ & $2.0 \mathrm{abc}$ & $5.8 \mathrm{~b}$ & $2.3 \mathrm{~b}$ & $0.8 \mathrm{ab}$ & $2.3 \mathrm{~b}$ \\
\hline $80 \% \mathrm{FB}$ & $6.4 \mathrm{~b}$ & $2.6 \mathrm{ab}$ & $6.9 \mathrm{~b}$ & $2.7 \mathrm{ab}$ & $1.2 \mathrm{a}$ & $3.0 \mathrm{ab}$ \\
\hline Petal fall & $3.6 \mathrm{c}$ & $1.3 \mathrm{c}$ & $3.6 \mathrm{c}$ & $2.0 \mathrm{~b}$ & $0.7 \mathrm{~b}$ & $2.0 \mathrm{~b}$ \\
\hline Hand thinned control, 35 DAFB & $9.7 \mathrm{a}$ & $2.7 \mathrm{a}$ & $9.2 \mathrm{a}$ & $3.6 \mathrm{a}$ & $1.0 \mathrm{ab}$ & $3.4 \mathrm{a}$ \\
\hline \multicolumn{7}{|c|}{ 'Arctic Sweet' 2008} \\
\hline Pink & $3.4 \mathrm{~b}$ & $1.5 \mathrm{a}$ & $3.7 \mathrm{~b}$ & $1.2 \mathrm{~b}$ & $0.6 \mathrm{ab}$ & $1.4 \mathrm{~b}$ \\
\hline $20 \% \mathrm{FB}$ & $3.4 \mathrm{~b}$ & $1.3 \mathrm{a}$ & $3.7 \mathrm{~b}$ & $0.9 \mathrm{bc}$ & $0.6 \mathrm{ab}$ & $1.2 \mathrm{~b}$ \\
\hline $80 \% \mathrm{FB}$ & $2.0 \mathrm{c}$ & $0.7 \mathrm{~b}$ & $2.3 \mathrm{c}$ & $0.8 \mathrm{c}$ & $0.4 \mathrm{~b}$ & $1.1 \mathrm{~b}$ \\
\hline Petal fall & $2.8 \mathrm{bc}$ & $0.8 \mathrm{~b}$ & $3.0 \mathrm{bc}$ & $1.0 \mathrm{bc}$ & $0.5 \mathrm{~b}$ & $1.2 \mathrm{~b}$ \\
\hline Hand thinned control, 35 DAFB & $5.5 \mathrm{a}$ & $1.4 \mathrm{a}$ & $5.6 \mathrm{a}$ & $1.7 \mathrm{a}$ & $0.8 \mathrm{a}$ & $2.1 \mathrm{a}$ \\
\hline \multicolumn{7}{|c|}{ 'Arctic Sweet' 2009} \\
\hline Pink, $150 \mathrm{rpm}$ & $2.9 \mathrm{ab}$ & $0.7 \mathrm{ab}$ & $2.9 \mathrm{ab}$ & $1.1 \mathrm{ab}$ & $0.3 \mathrm{a}$ & $1.1 \mathrm{~b}$ \\
\hline Pink, $120 \mathrm{rpm}$ & $3.3 \mathrm{a}$ & $0.9 \mathrm{a}$ & $3.5 \mathrm{a}$ & $1.4 \mathrm{a}$ & $0.4 \mathrm{a}$ & $1.5 \mathrm{a}$ \\
\hline $80 \% \mathrm{FB}$ & $2.2 \mathrm{~b}$ & $0.7 \mathrm{ab}$ & $2.4 \mathrm{~b}$ & $0.7 \mathrm{~b}$ & $0.3 \mathrm{a}$ & $0.9 \mathrm{~b}$ \\
\hline Petal fall & $2.2 \mathrm{~b}$ & $0.7 \mathrm{~b}$ & $2.4 \mathrm{~b}$ & $1.0 \mathrm{~b}$ & $0.3 \mathrm{a}$ & $1.1 \mathrm{~b}$ \\
\hline Hand thinned control, 35 DAFB & $3.0 \mathrm{ab}$ & $0.9 \mathrm{ab}$ & $3.1 \mathrm{a}$ & $1.0 \mathrm{~b}$ & $0.4 \mathrm{a}$ & $1.2 \mathrm{ab}$ \\
\hline
\end{tabular}

Sugar Giant, 2008

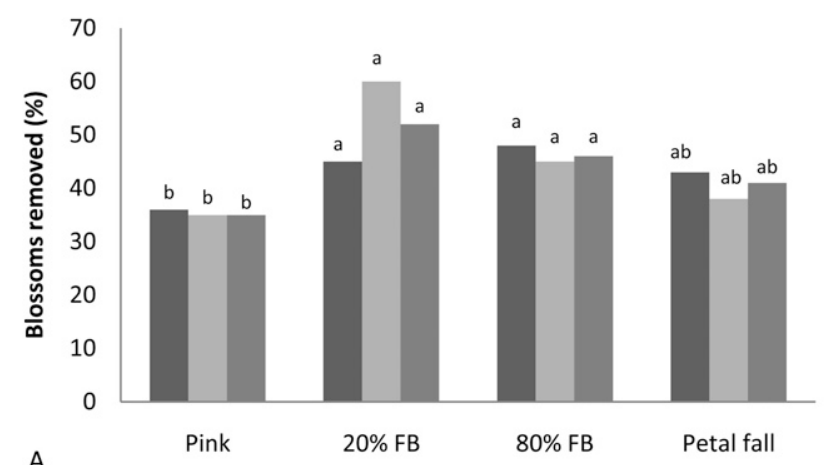

Sugar Giant, 2009

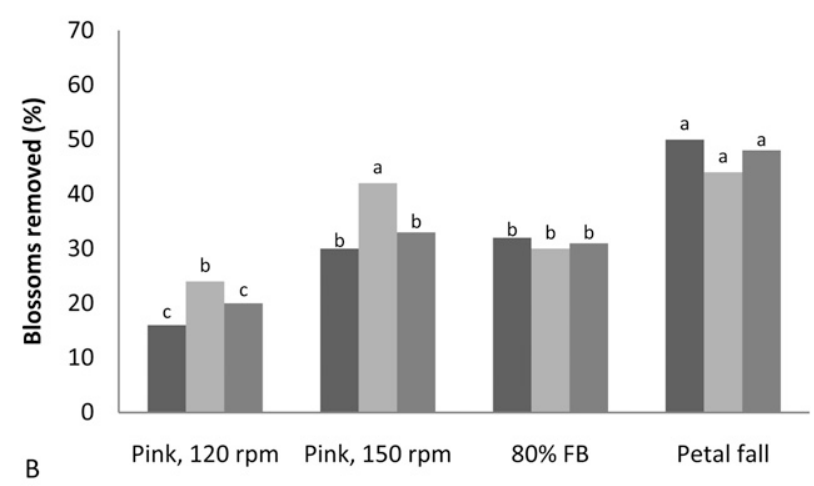

Arctic Sweet, 2008

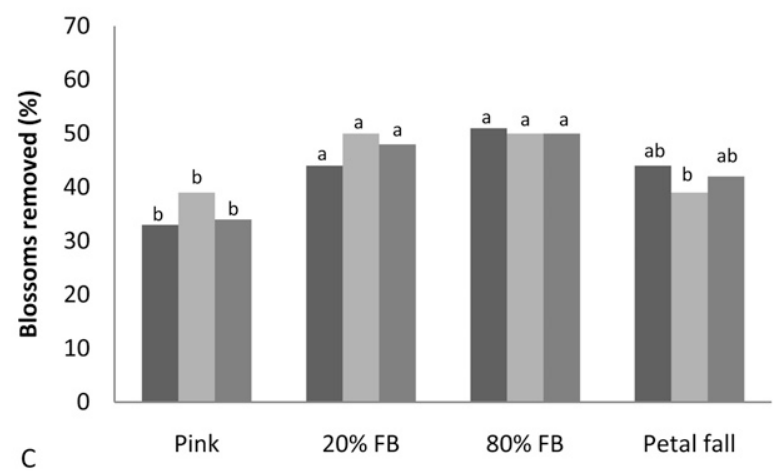

Arctic Sweet, 2009

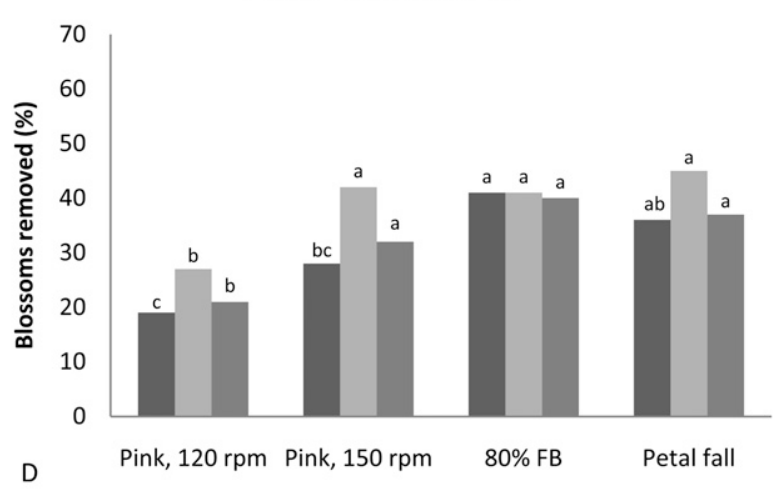

\section{Upper canopy - Lower canopy a Scaffold}

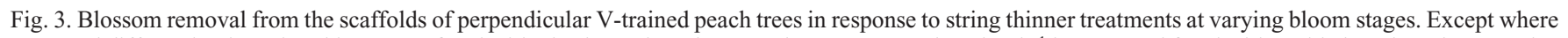
noted differently, the string thinner was fitted with plastic cords and operated at $180 \mathrm{rpm}$ and $4.0 \mathrm{~km} \cdot \mathrm{h}^{-1}$ in 2008 and fitted with molded cords and operated at $150 \mathrm{rpm}$ and $4.0 \mathrm{~km} \cdot \mathrm{h}^{-1}$ in $2009 . \mathrm{FB}=$ full bloom. Mean separation within cultivars and years by Fisher's protected least significant difference at $P \leq 0.05$. 
follow-up hand thinning time compared with green fruit thinning alone (hand thinned control, 35 to 40 DAFB) by $51 \%, 41 \%, 42 \%$, and $22 \%$ for 'Sugar Giant' and 'Arctic Sweet' in Years 1 and 2, respectively. These percentages parallel the reductions in crop load.

Follow-up hand thinning costs for the green fruit thinned control treatments averaged $\$ 1221 /$ ha in 2008 and $\$ 297 /$ ha in 2009 (Table 3). The best treatments resulted in a thinning savings of $\$ 415 /$ ha to $\$ 530 /$ ha in 2008 and $\$ 45 /$ ha to $\$ 67 /$ ha in 2009 . The bloom, fruit set, and follow-up hand thinning data confirm previous reports indicating the importance of careful assessment of bloom density to determine best use of mechanical thinning technology (Baugher et al., 2009, 2010; Schupp et al., 2008).

Fruit size and yield comparisons. Average fruit diameter was unaffected by thinning treatments in the 2009 low bloom density year (Table 4). The 2009 size distribution of 'Arctic Sweet' fruit also was unaffected, but the percentage of 'Sugar Giant' fruit in higher market value size categories was increased in the $80 \% \mathrm{FB}$ and higher rpm pink treatments. In 2008, average 'Sugar Giant' fruit diameter was increased by the $20 \%$ FB treatment, and average 'Arctic Sweet' fruit diameter was increased by the petal fall treatment. In addition, the percentage of fruit in the " 7.0 $\mathrm{cm}$ or greater" size category was increased by all bloom stage treatments in both cultivars, and the percentage of fruit in the " 7.6 $\mathrm{cm}$ or greater" size category was increased by bloom treatments in 'Sugar Giant'. Previous research showed no difference in effects on fruit size in the upper versus lower canopy (Schupp et al., 2008). Although total calculated yield of mechanically thinned trees was sometimes reduced compared with hand thinned control trees, yield of high market value size fruit $(7.6 \mathrm{~cm}$ or greater and $7.0 \mathrm{~cm}$ or greater for 'Sugar Giant' and 'Arctic Sweet', respectively) was sometimes increased. This contrasts earlier research in which there were more consistent increases in high market value yield (Baugher et al., 2010; Schupp et al., 2008). A 2008 mechanical thinning trial in which detailed yield data were collected at each harvest date demonstrated that early harvest yield of mechanically blossom thinned trees was greater than early yield of trees in hand thinned control and nonthinned treatments (Baugher et al., 2009). Fruit quality of the petal fall treatments was carefully assessed, and less than $1 \%$ of the peach or nectarine fruit had scars or other injuries that may have been caused by the string thinner.

Realized economic savings. The savings in hand thinning time and increases in fruit size associated with the bloom stage treatments increased the value of the peach and nectarine crops beyond that of hand thinning alone (Table 3). In 2008, reductions in follow-up hand thinning time had a significant effect on net positive economic impact, whereas in 2009, increases in fruit size were more important. For example, although the 2009 'Arctic Sweet' pink treatments increased follow-up hand thinning cost (Table
Table 2. Follow-up hand thinning time required in string thinner treatment at varying bloom stages compared with hand thinned controls in 2008 and 2009.

\begin{tabular}{lc}
\hline Thinning treatment ${ }^{\mathrm{z}}$ & $\begin{array}{c}\text { Hand thinning at } \\
\text { 35-40 DAFB }\left(\mathrm{h} \cdot \mathrm{ha}^{-1}\right)\end{array}$ \\
\hline Pink & 'Sugar Giant' 2008 \\
$20 \% \mathrm{FB}$ & $104.2 \mathrm{~b}^{\mathrm{x}}$ \\
$80 \% \mathrm{FB}$ & $68.4 \mathrm{c}$ \\
Petal fall & $74.8 \mathrm{c}$ \\
Hand thinned control, 35 DAFB & $69.2 \mathrm{c}$
\end{tabular}

Pink, $150 \mathrm{rpm}$

'Sugar Giant’ 2009

Pink, $120 \mathrm{rpm}$

$20.4 \mathrm{bc}$

$80 \%$ FB

$23.2 \mathrm{~b}$

$23.1 \mathrm{~b}$

Petal fall

Hand thinned control, 35 DAFB

$16.9 \mathrm{c}$

$28.5 \mathrm{a}$

Pink

'Arctic Sweet' 2008

$20 \%$ FB

$122.0 \mathrm{ab}$

$104.5 \mathrm{bc}$

$85.2 \mathrm{~b}$

$80 \%$ FB

$91.1 \mathrm{~b}$

Hand thinned control, 35 DAFB

$147.5 \mathrm{a}$

Pink, 150 rpm

'Arctic Sweet' 2009

Pink, $120 \mathrm{rpm}$

$36.7 \mathrm{ab}$

$41.5 \mathrm{a}$

$30.6 \mathrm{~b}$

$35.4 \mathrm{ab}$

Petal fall

$39.4 \mathrm{a}$

Hand thinned control, 35 DAFB

at $180 \mathrm{rpm}$ and

$4.0 \mathrm{~km} \cdot \mathrm{h}^{-1}$ in 2008 and fitted with molded cords and operated at $150 \mathrm{rpm}$ and $4.0 \mathrm{~km} \cdot \mathrm{h}^{-1}$ in 2009.

${ }^{\mathrm{y}} \mathrm{DAFB}=$ days after full bloom; FB = full bloom.

${ }^{x}$ Mean separation within cultivars and years by Fisher's protected least significant difference at $P \leq 0.05$.

Table 3. Follow-up hand thinning cost, thinning savings, and net economic impact as affected by string thinner treatments at varying bloom stages in 2008 and 2009.

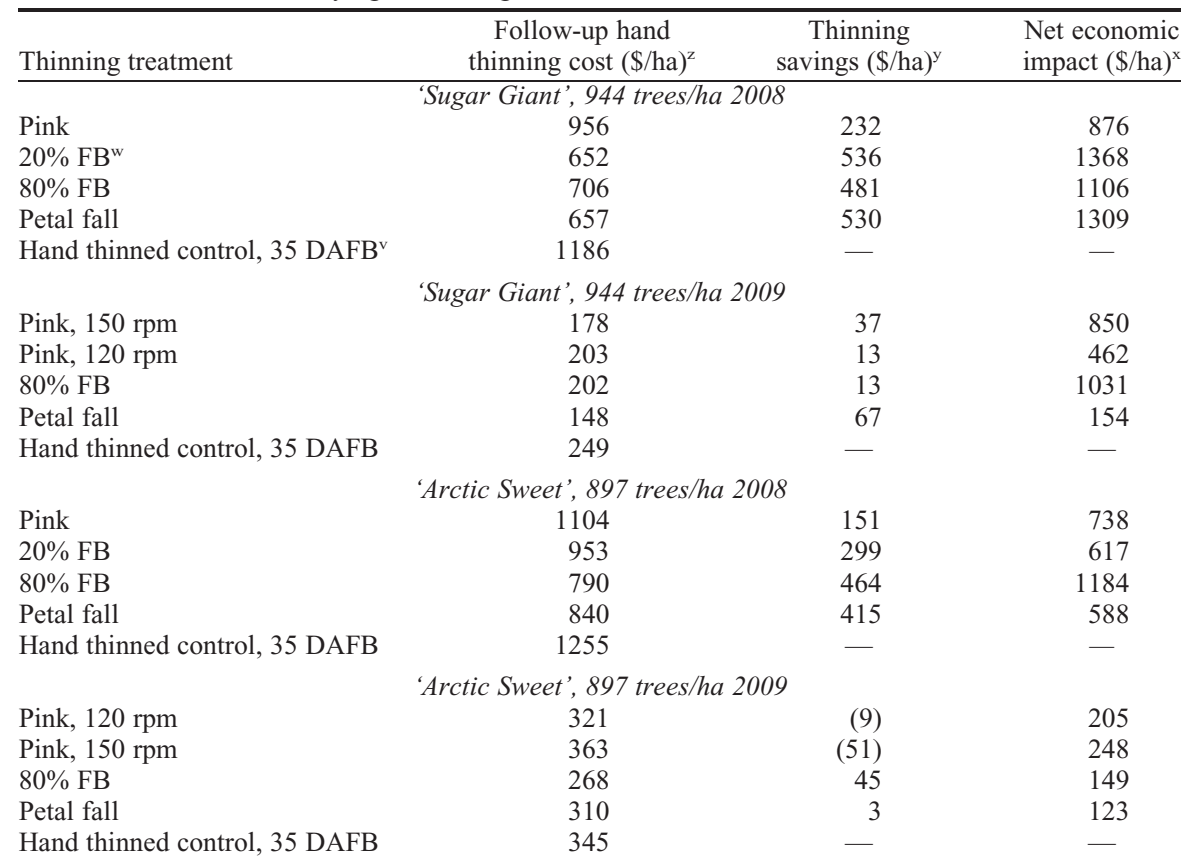

${ }^{\mathrm{z}}$ Follow-up hand thinning cost is based on a labor rate of $\$ 8.50 / \mathrm{h}$ in 2008 and $\$ 8.75 / \mathrm{h}$ in 2009 .

y Thinning savings includes reduced follow-up hand thinning inputs and added mechanical thinner, tractor, and labor inputs. Mechanical thinner cost is based on a 15-year useful life of equipment and $8 \%$ interest rate. Tractor cost is $\$ 12.00 / \mathrm{h}$; equipment operator cost is $\$ 12.00 / \mathrm{h}$.

${ }^{\mathrm{x}} \mathrm{Net}$ economic impact (realized economic savings) is defined as cost or benefit beyond hand thinning alone and takes into account reduced hand thinning inputs and increased value of fruit in higher size categories. Values in parentheses are negative.

${ }^{\mathrm{w}} \mathrm{FB}=$ full bloom; DAFB = days after full bloom.

3), the economic impact was increased as a result of a greater yield of high market value fruit (Table 4). Net positive economic impact (realized economic savings beyond hand thinning alone) ranged from $\$ 588 /$ ha to $\$ 1368 /$ ha in 2008 and $\$ 123 /$ ha to $\$ 1031 /$ ha in 2008. The economic savings were less consistent for petal fall treatments than for 
Table 4. Peach and nectarine fruit size, packout distribution, and high market value yield as affected by string thinner treatments at varying bloom stages in 2008 and 2009.

\begin{tabular}{|c|c|c|c|c|c|}
\hline \multirow[b]{2}{*}{ Thinning treatment } & \multirow[b]{2}{*}{$\begin{array}{l}\text { Fruit diam } \\
\qquad(\mathrm{cm})^{\mathrm{z}}\end{array}$} & \multicolumn{2}{|c|}{ Fruit in high market value size categories $(\%)^{z}$} & \multirow[b]{2}{*}{$\begin{array}{l}\text { Total yield } \\
\left(\mathrm{kg} \cdot \mathrm{ha}^{-1}\right)^{\mathrm{y}}\end{array}$} & \multirow[b]{2}{*}{$\begin{array}{c}\text { Yield of high market } \\
\text { value size fruit }\left(\mathrm{kg} \cdot \mathrm{ha}^{-1}\right)^{\mathrm{x}}\end{array}$} \\
\hline & & $\begin{array}{c}\text { Fruit } 7.0 \mathrm{~cm} \\
\text { or greater }(\%)\end{array}$ & $\begin{array}{l}\text { Fruit } 7.6 \mathrm{~cm} \\
\text { or greater }(\%)\end{array}$ & & \\
\hline \multicolumn{6}{|c|}{ 'Sugar Giant’ 2008} \\
\hline Pink & $7.8 \mathrm{ab}^{\mathrm{v}}$ & $100 \mathrm{a}$ & $95 \mathrm{a}$ & $22,221 \mathrm{a}$ & $21,349 \mathrm{a}$ \\
\hline $20 \% \mathrm{FB}^{\mathrm{w}}$ & $8.0 \mathrm{a}$ & $100 \mathrm{a}$ & $100 \mathrm{a}$ & $15,936 \mathrm{~b}$ & $15,936 \mathrm{~b}$ \\
\hline $80 \% \mathrm{FB}$ & $7.7 \mathrm{ab}$ & $100 \mathrm{a}$ & $94 \mathrm{a}$ & $19,154 \mathrm{~b}$ & $18,323 \mathrm{ab}$ \\
\hline Petal fall & $7.9 \mathrm{ab}$ & $100 \mathrm{a}$ & 99 a & $16,947 \mathrm{~b}$ & $16,760 \mathrm{~b}$ \\
\hline Hand thinned control, 35 DAFB & $7.4 \mathrm{~b}$ & $99 \mathrm{~b}$ & $78 \mathrm{~b}$ & 23,604 a & $19,115 \mathrm{a}$ \\
\hline \multicolumn{6}{|c|}{ 'Sugar Giant' 2009} \\
\hline Pink, $150 \mathrm{rpm}$ & $7.9 \mathrm{a}$ & $92 \mathrm{a}$ & $52 \mathrm{ab}$ & 8,444 b & $4,948 \mathrm{ab}$ \\
\hline Pink, 120 rpm & $7.8 \mathrm{a}$ & $90 \mathrm{ab}$ & $44 \mathrm{bc}$ & $10,099 \mathrm{ab}$ & $4,879 \mathrm{ab}$ \\
\hline $80 \% \mathrm{FB}$ & $7.9 \mathrm{a}$ & $93 \mathrm{a}$ & $61 \mathrm{a}$ & $10,453 \mathrm{ab}$ & $6,911 \mathrm{a}$ \\
\hline Petal fall & $7.7 \mathrm{a}$ & $90 \mathrm{ab}$ & $36 \mathrm{c}$ & $9,645 \mathrm{ab}$ & $3,872 \mathrm{~b}$ \\
\hline Hand thinned control, 35 DAFB & $7.7 \mathrm{a}$ & $84 \mathrm{~b}$ & $36 \mathrm{c}$ & $10,835 \mathrm{a}$ & $4,673 \mathrm{ab}$ \\
\hline \multicolumn{6}{|c|}{ 'Arctic Sweet' 2008} \\
\hline Pink & $6.7 \mathrm{a}$ & $42 \mathrm{a}$ & $14 \mathrm{a}$ & $-^{\mathrm{u}}$ & - \\
\hline $20 \% \mathrm{FB}$ & $6.6 \mathrm{a}$ & $37 \mathrm{a}$ & $7 \mathrm{a}$ & - & - \\
\hline $80 \% \mathrm{FB}$ & $6.6 \mathrm{a}$ & $48 \mathrm{a}$ & $6 \mathrm{a}$ & - & - \\
\hline Petal fall & $6.5 \mathrm{~b}$ & $38 \mathrm{a}$ & $15 \mathrm{a}$ & - & - \\
\hline Hand thinned control, 35 DAFB & $6.5 \mathrm{~b}$ & $33 \mathrm{~b}$ & $8 \mathrm{a}$ & - & - \\
\hline \multicolumn{6}{|c|}{ 'Arctic Sweet' 2009} \\
\hline Pink, 150 rpm & $6.4 \mathrm{a}$ & $18 \mathrm{a}$ & $1 \mathrm{a}$ & $6,483 \mathrm{a}$ & $1,395 \mathrm{a}$ \\
\hline Pink, 120 rpm & $6.4 \mathrm{a}$ & $16 \mathrm{a}$ & $1 \mathrm{a}$ & $7,994 \mathrm{a}$ & $1,767 \mathrm{a}$ \\
\hline $80 \% \mathrm{FB}$ & $6.4 \mathrm{a}$ & $10 \mathrm{a}$ & $0 \mathrm{a}$ & $6,666 \mathrm{a}$ & $863 \mathrm{c}$ \\
\hline Petal fall & $6.4 \mathrm{a}$ & $14 \mathrm{a}$ & $0 \mathrm{a}$ & 6,488 a & $1,162 \mathrm{~b}$ \\
\hline Hand thinned control, 35 DAFB & $6.4 \mathrm{a}$ & $7 \mathrm{a}$ & $0 \mathrm{a}$ & $7,128 \mathrm{a}$ & $680 \mathrm{c}$ \\
\hline
\end{tabular}

${ }^{2}$ Fruit diameter and packout distribution determined on 40 fruit harvested per treatment from each of six replicates.

${ }^{y}$ Yield calculated from fruit counts per scaffold and percent size distribution at harvest.

'High market value fruit are all fruit $7.62 \mathrm{~cm}$ or greater diameter for 'Sugar Giant' and all fruit $6.985 \mathrm{~cm}$ or greater for 'Arctic Sweet'.

${ }^{\mathrm{w}} \mathrm{FB}=$ full bloom; DAFB = days after full bloom.

'Mean separation within columns, cultivars, and years by Fisher's protected least significant difference at $P \leq 0.05$.

"No yield estimates conducted.

treatments applied earlier. This finding further illustrates the potential fruit size benefit of earlier thinning times shown in this and previous studies (Baugher et al., 2010; Schupp et al., 2008).

Implications for growers. Before the initiation of this research on bloom stage, peach producers who were assessing whether string blossom thinning was a cost-effective option in a given situation asked questions about the range of thinning timings. Some were concerned about spring freezes and wanted to thin as late as possible, and some wanted to obtain as many hours of use from the mechanical thinner as possible. Based on this 2-year study on one peach and one nectarine cultivar, the thinning timeframe is from pink to petal fall, which is good news for both commercial situations. The thinning time frame for the two cultivars with similar bloom development was 10 Apr. to 25 Apr. in 2008 and 15 Apr. to 1 May in 2009. The length of the bloom period was similar in both years, and the number of days a single cultivar could be successfully thinned was 26 d. Growers who have additional cultivars with earlier and/or later bloom development may find that they have an additional week to complete the mechanical thinning operation. In other years and production regions, the timeframe may be less or more, depending on weather conditions (Baugher et al., 2010). This study demonstrated that it is more difficult to remove blossoms at pink compared with other bloom stages, which indicates that producers will need to thin more aggressively at earlier bloom stages, e.g., by increasing spindle rpm. Previous research suggested that increasing tractor speed or increasing number of strings will also increase string thinner performance (Baugher et al., 2010). A benefit of using the string thinner at earlier stages of bloom development is that there can be an increased effect on fruit size and market value. Mechanical blossom thinning often reduces labor costs and increases fruit size, and both should be considered in deciding when to thin.

\section{Literature Cited}

Baugher, T.A., J. Schupp, K. Ellis, J. Remcheck, E. Winzeler, R. Duncan, S. Johnson, K. Lewis, G. Reighard, G. Henderson, M. Norton, A. Dhaddey, and P. Heinemann. 2010. String blossom thinner designed for variable tree forms increases crop load management efficiency in trials in four United States peach-growing regions. HortTechnology 20:409-414.

Baugher, T.A., J. Schupp, K. Lesser, and K. Reichard. 2009. Horizontal string blossom thinner reduces labor input and increases fruit size in peach trees trained to open-center systems. HortTechnology 19:755-761.

Baugher, T.A., J. Schupp, S. Miller, M. Harsh, K. Lesser, and K. Reichard. 2008. Chemical and mechanical thinning of peaches. Proc. New England Vegetable and Fruit Conference Trade Show. Manchester, NH. p. 107-111.

Bertschinger, L., W. Stadler, F.P. Weibel, and R. Schumacher. 1998. New methods for an environmentally safe regulation of flower and fruit set and of alternate bearing of the apple crop. Acta Hort. 466:65-70.

Byers, R.E. 1999. Effects of bloom-thinning chemicals on peach fruit set. J. Tree Fruit Production 2:59-78.
Fallahi, E., B. Fallahi, J.R. McFerson, R.E. Byers, R.C. Ebel, R.T. Boozer, J. Pitts, and P.S. Wilkins. 2006. Tergitol-TMN-6 surfactant is an effective blossom thinner for stone fruits. HortScience 41:1243-1248.

Glozer, K. and J. Hasey. 2006. Mechanical thinning in cling peach. HortScience 41:995.

Harper, J.K., R.M. Crassweller, and D.E. Smith. 2002. Impact of apple rootstock/cultivar on processing market profitability. J. Amer. Pomological Soc. 56:112-117.

Klein, J.D. and S. Cohen. 2000. Thinning nectarines and peaches at flowering with organosilicone surfactants. HortScience 35:496 (abstr.).

Krawczyk, G. (ed.). 2010. 2010-2011 Pennsylvania tree fruit production guide. Penn State College of Agr. Sci. Bul. AGRS-045.

Osborne, J.L., T.L. Robinson, and R. ParraQuezada. 2005. Chemical blossom thinning agents reduce crop load of 'Rising Star' peach in New York. Acta Hort. 727:423-428.

Schupp, J.R., T. Auxt Baugher, S.S. Miller, R.M. Harsh, and K.M. Lesser. 2008. Mechanical thinning of peach and apple trees reduces labor input and increases fruit size. HortTechnology 18:660-670.

Stover, E.W. and D.W. Greene. 2005. Environmental effects on the performance of foliar applied plant growth regulators. HortTechnology 15:214-221.

U.S. Department of Agriculture. 2009. USDA agricultural marketing service report. USDA fruit and vegetable market news. 10 Dec. 2009. $<\mathrm{http} / /$ marketnews.usda.gov/portal/fv?paf_dm= full\&paf_gear_id=1200002\&startIndex $=1 \& \mathrm{dr}=1$ \&rowDisplayMax $=25 \&$ repType $=$ termPriceDaily $\& \mathrm{dr}=1 \&$ loc Name $=\&$ commAbr $=\mathrm{PCH} \&$ comm Name $=$ PEACHES $>$.

Wilkins, B.S., R.C. Ebel, W.A. Dozier, J. Pitts, and R. Boozer. 2004. Tergitol TMN-6 for thinning peach blossoms. HortScience 39:1611-1613. 